\title{
Changing trends in eclampsia and increasing cesarean delivery - an interesting retrospective study from a tertiary care hospital of Raipur, Chhattisgarh, India
}

\section{Abha Singh, Chandrashekhar Shrivastava*}

Department of Obstetrics \& Gynaecology, Pt. Jawahar Lal Nehru Memorial Medical College, Raipur, Chhattisgarh, India

Received: 10 January 2016

Accepted: 01 March 2016

\section{*Correspondence:}

Dr. Chandrashekhar Shrivastava,

E-mail: chandan_1708@yahoo.co.in

Copyright: () the author(s), publisher and licensee Medip Academy. This is an open-access article distributed under the terms of the Creative Commons Attribution Non-Commercial License, which permits unrestricted non-commercial use, distribution, and reproduction in any medium, provided the original work is properly cited.

\section{ABSTRACT}

Background: Despite all advances in obstetrical care eclampsia remains a puzzle and it still kills. Due to good antenatal and peripartum care, developed countries have a minimum incidence, while such changes have not occurred in developing countries especially in peripheral areas. So the incidence remains high in developing countries like India. Fetomaternal outcome in eclampsia depends on nature of convulsion quality and speed of care. Obstetrical management with the objective "Sooner the delivery betters the prognosis" has been shown to play great role in improving fetomaternal outcome.

Methods: It's a retrospective observational study done among all admitted eclamptic women over the period of 10 years from Jan 2005 to Dec 2014 in the Department of Obstetrics and Gynecology, Pt. Jawahar Lal Nehru Memorial Medical College \& Dr B. R. A. M. Hospital Raipur (CG), by reviewing maternal death register, admission register and antenatal record of women.

Results: A total of 1153 eclamptic women were admitted over 10 year study period. The incidence of eclampsia was $1.935 \%$. Out of total 298 Maternal deaths 131 were due to eclampsia (43.95\%). Most of the patients belonged to age 20-30 years, were with low parity and presented most commonly after 34 weeks of gestation with antepartum eclampsia. There was an increasing trend of DIC and HELLP related maternal morbidity and mortality. DIC was the most dreadful complication with the case fatality ratio of 50\%. The no of convulsion was associated with increased operative interference. We observed a better perinatal salvage by LSCS $(72.91 \%)$.There was an increasing trend of maternal death due to eclampsia over the 10 year study period. Increasing trend of cesarean delivery in eclamptic women was also observed from $37.09 \%$ in 2005 to $83.55 \%$ in 2014 . Better perinatal outcome was seen with lesser convulsion to delivery interval.

Conclusions: Contrary to various studies hypertensive disorder to be the fourth most common cause of maternal death in developing countries, eclampsia came out to be the leading cause of maternal mortality in our study. Better antenatal and peripartum care can reduce its occurrence and related morbidity and mortality. Optimum outcome can be achieved by the speed with which the peripartum care is given. Cesarean delivery is preferable if vaginal delivery is not anticipated within $8 \mathrm{hrs}$ as it gives better fetomaternal outcome.

Keywords: Eclampsia, Maternal mortality, Perinatal mortality, Cesarean section

\section{INTRODUCTION}

For a family or a society at large, there cannot be a worse situation than losing the mother due to pregnancy related complications or child birth. Worldwide "over half a million deaths occur every year, and of these, $99 \%$ deaths occur in developing countries". ${ }^{1}$

"The chances of maternal death is 1 in 4,000 to 1 in 10,000 in industrialized nation as compared to 1 in 15 to 
1 in 50 in low income countries". ${ }^{2}$ This disparity reflects poor health service.

One of the major contributors for maternal mortality is eclampsia, especially in our country. In the developed countries, the incidence has fallen considerably. ${ }^{3}$ The Maternal Mortality for eclampsia ranges from $1.8 \%$ $43.1 \% .^{3}$

Prompt diagnosis at the onset during antenatal period, medical management to keep the B.P. under control as well as a balanced judgment for time and route of delivery plays an important role in optimizing the fetomaternal outcome. ${ }^{3-5}$

The present study is undertaken to analyse eclampsia related morbidity and mortality and its changing trends in our institute over a period of 10 years. Our hospital is a tertiary care hospital. We cater to large number of women referred from PHCs, CHCs and other private hospitals.

The aim and objectives of the study was to the changing trends in eclampsia and role of caesarean section in eclamptic women in improving fetomaternal outcome.

\section{METHODS}

This is a retrospective observational study done among admitted women with eclampsia in obstetrical ward/ICU from Jan 2005 to Dec 2014 in the department of Obstetrics and Gynecology, Pt. Jawahar Lal Nehru Memorial Medical College, Raipur, Chhattisgarh, India.

We reviewed maternal death register, admission \& delivery register and all the medical records related to the women and respective information regarding sociodemographic profile, clinical profile and fetomaternal outcome were retrieved.

The research protocol was approved by Ethical committee. As it was an observational study not an interventional study, no informed consent was needed.

Data was compiled in MS Excel and checked for its completeness and correctness. Then it was analysed.

\section{RESULTS}

A total of 1153 women with eclampsia were admitted in our institute from Jan 2005 to Dec 2014. During this period the total number of deliveries were 59571 and total number of maternal mortality were 298 , of which $131(43.95 \%)$ were due to eclampsia. The incidence of eclampsia showed a rising trend from $1.75 \%$ in 2005 to $2.03 \%$ in 2011 (1.95\% in 2014.)

Table 1 shows the demographic profile of women. Most of them were in the age group 20-30 years with low parity. They presented commonly with ante partum eclampsia, mostly unbooked and after 34 wks of gestation. $79.79 \%$ women were referred from various other hospitals and health centers.

Table 1: Demographic profile.

\begin{tabular}{|ll|}
\hline Characteristics & $(\mathbf{n}=1153)$ \\
\hline Age in years & \\
\hline$<20$ & $151(13.09 \%)$ \\
\hline $21-24$ & $529(45.88 \%)$ \\
\hline $25-29$ & $272(23.59 \%)$ \\
\hline $30-34$ & $134(11.62 \%)$ \\
\hline $35-39$ & $51(4.42 \%)$ \\
\hline 40 and above & $16(1.38 \%)$ \\
\hline Booking status & \\
\hline Booked & $109(9.45 \%)$ \\
\hline Unbooked & $1044(90.54 \%)$ \\
\hline Parity & \\
\hline 1 & $337(29.22 \%)$ \\
\hline 2 & $297(25.75 \%)$ \\
\hline 3 & $153(13.26 \%)$ \\
\hline 4 & $125(10.84 \%)$ \\
\hline $5+$ above & $241(20.90 \%)$ \\
\hline Gestational age (in weeks) & \\
\hline$<28$ & $76(6.59 \%)$ \\
\hline $28-34$ & $177(15.35 \%)$ \\
\hline $34-37$ & $384(33.30 \%)$ \\
\hline$>37$ & $516(44.75 \%)$ \\
\hline Referred & $920(79.79 \%)$ \\
\hline Types of eclampsia & $867(75.19 \%)$ \\
\hline Antepartum & $79(6.85 \%)$ \\
\hline Intrapartum & $211(18.30 \%)$ \\
\hline Postpartum & \\
\hline & \\
\hline & \\
\hline & \\
\hline
\end{tabular}

The trends in maternal morbidity due to eclampsia are seen in Table 2. The incidence of DIC increased from $6.89 \%$ to $14.47 \%$, HELLP increased from $14.94 \%$ to $31.57 \%$ \& RF from $10.34 \%$ to $26.97 \%$. Thus an overall increase by more than double was noted in each complication. A significant increased mortality trend was observed due to DIC, whereas a reduction in mortality due to pulmonary edema (PE) has been noted $(3.44 \%$ in 2005 to $0.65 \%$ in 2014 ).

Higher caesarean delivery rates were seen in women coming with an increased number of convulsions. (Table 3) Cesarean was the preferred mode of delivery when cervix was unfavourable \& early delivery was not likely. In women who were admitted with history of more than 6 convulsions were subjected to cesarean delivery immediately after preliminary preparations. Thus the cesarean rate was $85.66 \%$ in these women as compared to only $48.01 \%$ in women with history of 1 convulsion.

Delivery is the definitive treatment for eclampsia. As far as mode of delivery was concerned, a higher perinatal mortality was observed with vaginal delivery (44.6\%) as compared to cesarean delivery where perinatal mortality remained close to $11.9 \%$ (Table 4 ). 
Table 2: Maternal morbidity vs. mortality.

\begin{tabular}{|c|c|c|c|c|c|c|c|c|c|c|c|}
\hline \multirow[b]{2}{*}{ Yr. } & \multirow{2}{*}{$\begin{array}{l}\text { No of } \\
\text { eclam } \\
\text { psia }\end{array}$} & \multirow{2}{*}{$\begin{array}{l}\text { Pulmonary } \\
\text { Morbi- } \\
\text { dity }\end{array}$} & \multirow{2}{*}{$\begin{array}{l}\text { Edema } \\
\text { Morta- } \\
\text { lity }\end{array}$} & \multicolumn{2}{|l|}{ DIC } & \multicolumn{2}{|l|}{ HELLP } & \multicolumn{2}{|l|}{ CVA } & \multicolumn{2}{|c|}{ Renal Failure } \\
\hline & & & & $\begin{array}{l}\text { Morbi- } \\
\text { dity }\end{array}$ & $\begin{array}{l}\text { Morta- } \\
\text { lity }\end{array}$ & $\begin{array}{l}\text { Morbi- } \\
\text { dity }\end{array}$ & $\begin{array}{l}\text { Morta- } \\
\text { lity }\end{array}$ & $\begin{array}{l}\text { Morbi- } \\
\text { dity }\end{array}$ & $\begin{array}{l}\text { Morta- } \\
\text { lity }\end{array}$ & $\begin{array}{l}\text { Morbi- } \\
\text { dity }\end{array}$ & $\begin{array}{l}\text { Morta- } \\
\text { lity }\end{array}$ \\
\hline 05 & 87 & $\begin{array}{l}15 \\
(17.2)\end{array}$ & $\begin{array}{l}3 \\
(3.44)\end{array}$ & $\begin{array}{l}6 \\
(6.89)\end{array}$ & $\begin{array}{l}2 \\
(2.29)\end{array}$ & $\begin{array}{l}13 \\
(14.94)\end{array}$ & $\begin{array}{l}1 \\
(1.14)\end{array}$ & $\begin{array}{l}11 \\
(12.64)\end{array}$ & $0(0)$ & (10.34) & $0(0)$ \\
\hline 06 & 82 & $\begin{array}{l}9 \\
(10.9)\end{array}$ & $\begin{array}{l}2 \\
(2.43)\end{array}$ & $\begin{array}{l}5 \\
(6.09)\end{array}$ & $\begin{array}{l}2 \\
(2.43)\end{array}$ & $\begin{array}{l}14 \\
(17.07)\end{array}$ & $\begin{array}{l}1 \\
(1.21)\end{array}$ & $\begin{array}{l}9 \\
(10.97)\end{array}$ & $\begin{array}{l}1 \\
(1.21)\end{array}$ & $\begin{array}{l}10 \\
(12.19)\end{array}$ & $\begin{array}{l}1 \\
(1.21)\end{array}$ \\
\hline 07 & 91 & $\begin{array}{l}17 \\
(18.68)\end{array}$ & $\begin{array}{l}1 \\
(1.09)\end{array}$ & $\begin{array}{l}7 \\
(7.69)\end{array}$ & $\begin{array}{l}3 \\
(3.29)\end{array}$ & $\begin{array}{l}14 \\
(15.38)\end{array}$ & $\begin{array}{l}1 \\
(1.09)\end{array}$ & $\begin{array}{l}7 \\
(7.69)\end{array}$ & $\begin{array}{l}1 \\
(1.09)\end{array}$ & $\begin{array}{l}14 \\
(15.38)\end{array}$ & $\begin{array}{l}2 \\
(2.19)\end{array}$ \\
\hline 08 & 98 & $\begin{array}{l}15 \\
(15.3)\end{array}$ & $\begin{array}{l}2 \\
(2.04)\end{array}$ & $\begin{array}{l}7 \\
(7.14)\end{array}$ & $\begin{array}{l}3 \\
(3.06)\end{array}$ & $\begin{array}{l}19 \\
(19.38)\end{array}$ & $\begin{array}{l}2 \\
(2.04)\end{array}$ & $\begin{array}{l}9 \\
(9.18)\end{array}$ & $\begin{array}{l}1 \\
(1.02)\end{array}$ & $16(16.32$ & $0(0)$ \\
\hline 09 & 113 & $\begin{array}{l}18 \\
(15.92)\end{array}$ & $\begin{array}{l}2 \\
(1.76)\end{array}$ & $\begin{array}{c}5 \\
(4.42) \\
\end{array}$ & $\begin{array}{l}2 \\
(1.76)\end{array}$ & $\begin{array}{l}16 \\
(14.15)\end{array}$ & $\begin{array}{l}2 \\
(1.76)\end{array}$ & $\begin{array}{l}8 \\
(7.07)\end{array}$ & $0(0)$ & $\begin{array}{l}19 \\
(16.8)\end{array}$ & $\begin{array}{l}1 \\
(0.88)\end{array}$ \\
\hline 10 & 117 & $\begin{array}{l}10 \\
(8.5)\end{array}$ & $\begin{array}{l}2 \\
(1.70)\end{array}$ & $\begin{array}{l}15 \\
(12.82)\end{array}$ & $\begin{array}{l}6 \\
(5.12)\end{array}$ & $\begin{array}{l}20 \\
(17.09)\end{array}$ & $\begin{array}{l}3 \\
(2.56)\end{array}$ & $\begin{array}{l}10 \\
(8.54)\end{array}$ & $\begin{array}{l}1 \\
(0.85)\end{array}$ & $\begin{array}{l}21 \\
(17.94)\end{array}$ & $\begin{array}{l}3 \\
(2.56)\end{array}$ \\
\hline 11 & 122 & $\begin{array}{l}14 \\
(11.47)\end{array}$ & $\begin{array}{l}2 \\
(1.63)\end{array}$ & $\begin{array}{l}16 \\
(13.1) \\
\end{array}$ & $\begin{array}{l}7 \\
(5.73) \\
\end{array}$ & $\begin{array}{l}22 \\
(18.03)\end{array}$ & $\begin{array}{l}4 \\
(3.27)\end{array}$ & $\begin{array}{l}9 \\
(7.37)\end{array}$ & $\begin{array}{l}1 \\
(0.81)\end{array}$ & $\begin{array}{l}37 \\
(30.32)\end{array}$ & $\begin{array}{l}2 \\
(1.63)\end{array}$ \\
\hline 12 & 142 & $\begin{array}{c}11 \\
(7.74)\end{array}$ & $2(1.40)$ & $\begin{array}{l}14 \\
(9.85)\end{array}$ & $\begin{array}{l}10 \\
(7.04)\end{array}$ & $\begin{array}{l}27 \\
(19.01)\end{array}$ & $\begin{array}{l}3 \\
(2.1)\end{array}$ & $\begin{array}{l}11 \\
(7.74)\end{array}$ & $\begin{array}{l}1 \\
(0.70)\end{array}$ & $\begin{array}{l}31 \\
(21.83)\end{array}$ & $\begin{array}{l}1 \\
(0.70)\end{array}$ \\
\hline 13 & 149 & $\begin{array}{l}15 \\
(10.06)\end{array}$ & $\begin{array}{l}2 \\
(1.34)\end{array}$ & $\begin{array}{l}17 \\
(11.40)\end{array}$ & $\begin{array}{l}11 \\
(7.38)\end{array}$ & $\begin{array}{l}31 \\
(20.80)\end{array}$ & $\begin{array}{l}4 \\
(2.68)\end{array}$ & $\begin{array}{l}10 \\
(6.71)\end{array}$ & $\begin{array}{l}2 \\
(1.34)\end{array}$ & $\begin{array}{l}35 \\
(23.48)\end{array}$ & $\begin{array}{l}5 \\
(3.35)\end{array}$ \\
\hline 14 & 152 & $\begin{array}{r}13 \\
(8.5)\end{array}$ & $\begin{array}{c}1 \\
(0.65)\end{array}$ & $\begin{array}{l}22 \\
(14.47)\end{array}$ & $\begin{array}{l}12 \\
(7.89)\end{array}$ & $\begin{array}{l}48 \\
(31.57)\end{array}$ & $\begin{array}{l}5 \\
(3.28)\end{array}$ & $\begin{array}{l}12 \\
(7.89)\end{array}$ & $\begin{array}{l}3 \\
(1.97)\end{array}$ & $\begin{array}{l}41 \\
(26.97)\end{array}$ & $\begin{array}{l}2 \\
(1.31)\end{array}$ \\
\hline Total & 1153 & 137 & 19 & 116 & 58 & 224 & 26 & 96 & 11 & 233 & 17 \\
\hline
\end{tabular}

Percentages are shown in brackets

Table 3: Number of convulsions and type of delivery.

\begin{tabular}{|c|c|c|c|c|}
\hline \multirow[b]{2}{*}{$\begin{array}{l}\text { No. of } \\
\text { convulsions }\end{array}$} & \multirow[b]{2}{*}{$\mathrm{N}=1153$} & \multicolumn{3}{|c|}{ Mode of delivery ( $N=1142)$} \\
\hline & & $\begin{array}{l}\text { LSCS } \\
(\%)\end{array}$ & $\begin{array}{l}\text { Vaginal } \\
(\%)\end{array}$ & $\begin{array}{l}\text { Instrumental } \\
\text { vaginal (\%) }\end{array}$ \\
\hline 1 & 227 & $\begin{array}{l}109 \\
(48.01)\end{array}$ & $\begin{array}{l}95 \\
(41.85)\end{array}$ & $\begin{array}{l}21 \\
(9.25)\end{array}$ \\
\hline $2-4$ & 344 & $\begin{array}{l}145 \\
(42.15)\end{array}$ & $\begin{array}{l}151 \\
(43.89)\end{array}$ & $\begin{array}{l}45 \\
(13.08)\end{array}$ \\
\hline $5-6$ & 268 & $\begin{array}{l}208 \\
(77.61)\end{array}$ & $\begin{array}{l}46 \\
(17.16)\end{array}$ & $\begin{array}{l}11 \\
(4.10)\end{array}$ \\
\hline$>6$ & 314 & $\begin{array}{l}269 \\
(85.66)\end{array}$ & $\begin{array}{l}38 \\
(12.10)\end{array}$ & $\begin{array}{l}4 \\
(1.27)\end{array}$ \\
\hline Total & 1153 & 731 & 330 & 81 \\
\hline
\end{tabular}

Table 4: Modes of delivery and fetal outcome.

\begin{tabular}{|c|c|c|c|c|}
\hline $\begin{array}{l}\text { Mode of } \\
\text { delivery }\end{array}$ & $\begin{array}{l}\text { Total } \\
\text { delivery }\end{array}$ & Live baby & IUD & $\begin{array}{l}\text { Died in } \\
\text { Nursery }\end{array}$ \\
\hline Caesarean & 731 & $\begin{array}{l}533 \\
(72.91 \%)\end{array}$ & $\begin{array}{l}111 \\
(15.18 \%)\end{array}$ & $\begin{array}{l}87 \\
(11.90 \%)\end{array}$ \\
\hline Vaginal & 330 & $\begin{array}{l}122 \\
(36.96 \%)\end{array}$ & $\begin{array}{l}80 \\
(24.24 \%)\end{array}$ & $\begin{array}{l}128 \\
(38.78 \%)\end{array}$ \\
\hline $\begin{array}{l}\text { Instru- } \\
\text { mental } \\
\text { vaginal }\end{array}$ & 81 & $\begin{array}{l}32 \\
(39.50 \%)\end{array}$ & $12(14.81 \%$ & $\begin{array}{l}37 \\
(45.6 \%)\end{array}$ \\
\hline Total & 1142 & 687 & 203 & 252 \\
\hline
\end{tabular}

*11 women were died undelivered
Figure 1 shows an increasing trend of cesarean section in eclamptic women over the ten year study period. An important observation was a 3 fold rise in cesarean rates from $27.05 \%$ in 2005 to $83.55 \%$ in 2014 . However, the rate of vaginal delivery showed a decline from $46 \%$ (2005) to $12.5 \%$ (2014).

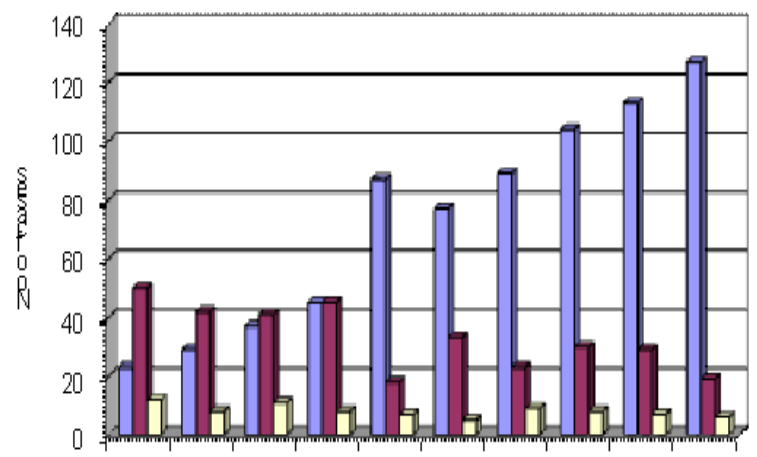

2005200620072008200920102011201220132014 Year

aCESAREAN GVAGINAL IINSTRUMENTALVAGINAL

Figure 1: Mode of delivery.

An improved fetal outcome was observed over the 10 year period in association with convulsion- delivery interval of 8 hours. This was mainly due to increased cesarean rates in this period (Figure 2). 


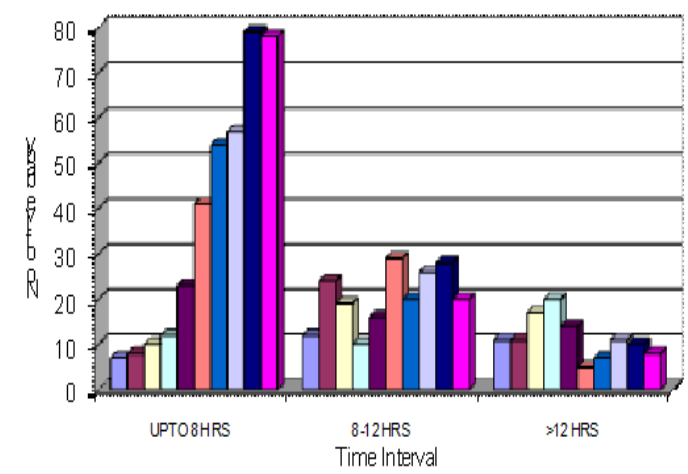

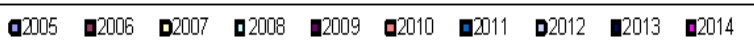

Figure 2: Convulsion to delivery internal \& perinatal outcome.

\section{DISCUSSION}

Incidence of eclampsia in our institute ranged from $1.75 \%$ in 2005 to $1.95 \%$ in 2014 . As per study conducted by WHO (2013) incidence in India is $2.2 \%$ whereas developed countries like UK and USA have incidence of $0.049 \%$ and $0.043 \%$ respectively. $^{6}$

Eclampsia contributed to $43.95 \%$ of total maternal mortality in our study. No change in trends were observed in age, parity and type of eclampsia as most of the women were in age group 21-30 years with low parity and with antepartum eclampsia. ${ }^{3,6,7}$ An increasing trend was seen in number of unbooked women. Though antepartum eclampsia was most common presentation, but the postpartum period was most vulnerable, as maximum maternal mortality occurred in that period $(91.60 \%)$. The incidence of PE, DIC, HELLP, CVA and RF among eclamptic women was $11.88 \%, 10.06 \%$, $19.42 \%, 8.32 \%$ and $20.20 \%$ respectively.

An increasing trend of morbidity and mortality was found in DIC and HELLP and decreasing trend of development of PE. The decline in the incidence of PE is attributable to better care of these women and availability of better ventilatory support in our institute. ${ }^{7}$ DIC was the most dreadful entity complicating eclampsia with a CFR of $50 \%$.

There was an increased operative interference as the number of convulsions increased [Table 3].

The perinatal mortality was least in cesarean delivery $(11.90 \%)$ and maximum with instrumental delivery (45.6\%). A study done by Lahiri et al showed low perinatal mortality of $9.2 \%$ with cesarean section similar to our study. They found highest mortality of $55 \%$ by vaginal delivery as opposed our study in which highest mortality was found in instrumental vaginal delivery $(45.6 \%){ }^{8}$
In developing countries like India, hemorrhage is still the most common cause of maternal death. We found a shifting paradigm in favour of eclampsia. This is comparable to studies done by Sarkar et al. and M Ashraf Ali et al. ${ }^{7,9}$

Mortality from eclampsia (i.e. CFR) ranges from $0 \%$ $1.8 \%$ in developed countries to as high as $15 \%$ in developing countries. ${ }^{5}$ Contrary to various Indian studies where CFR of eclampsia ranged from $2.74 \%$ to $4.96 \%$, we observed a high case fatality ratio of $11.36 \%{ }^{2,5,9} \mathrm{~A}$ study from Tanzania showed CFR of $7.89 \%$ and another study from Pakistan showed high CFR of $15.52 \%$ from eclampsia. ${ }^{1,8}$

There was an increasing trend of cesarean section in eclamptic women over the past 10 years, similar to various studies. ${ }^{3,6,8,11}$

Better perinatal outcome was observed when first convulsion to delivery interval was short (up to 8 hours). Similar findings were observed in two studies which showed that cesarean section within 6 hours of convulsions is associated with lesser perinatal morbidity and better perinatal outcome. ${ }^{12,13}$ Another study from West Bengal concluded improved prognosis of mother and baby by cutting short convulsion to delivery interval by early cesarean section within 2-4 hours. ${ }^{8}$

Maternal mortality of $5.88 \%$ was seen when cesarean was the chosen mode of delivery as opposed to mortality of $29.6 \%$ in instrumental vaginal delivery and $16.06 \%$ in vaginal delivery. Similar findings were observed by another comparative study which showed least maternal mortality of $5.5 \%$ in cesarean section verses mortality of $55 \%$ and $18 \%$ in vaginal delivery and instrumental vaginal delivery respectively. ${ }^{8}$

\section{CONCLUSION}

Earlier studies have shown that hemorrhage in the most common cause of maternal mortality in developing countries like India. In 2013 WHO (ICD-10) reported that eclampsia is only responsible for $7 \%$ of maternal death worldwide.

Contrary to these observations, eclampsia was the leading cause of maternal death in $43.95 \%$ of total maternal mortality in our study. These women died mainly of due to complications like DIC, HELLP and renal failure.

Prompt diagnosis \& timely decision for cesarean delivery, in women who come with more number of convulsions and in whom delivery is not anticipated within 8 hours of first convulsions, can result in saving the lives of mothers $\&$ babies.

The deaths due to pulmonary edema declined considerably over the past due to availability of better ventilator support. 
Though the maternal deaths due to eclampsia were found to be increased a significant reduction in perinatal mortality was observed. The study showed a definite shift towards cesarean delivery, which co related very well with lover perinatal mortality of $11.90 \%$. It was found that the earlier deaths were mainly due to the delay in convulsion to delivery interval. Delivery within 8 hours of $1^{\text {st }}$ convulsion was as optimal time for best maternal $\&$ perinatal outcome. Very few cesarean sections were done for other obstetrical indication other than eclampsia within 8 hours of $1^{\text {st }}$ convulsions. Thus cesarean was the chosen mode of delivery in most of the women.

\section{ACKNOWLEDGEMENTS}

The authors are thankful to all the faculty and technical staff of department of Obstetrics and Gynecology, Dr. BRAM Hospital, Pt. J. N. M. medical college, Raipur (C.G.) India, for their cooperation and support during the entire study period.

\section{Funding: Not required}

Conflict of interest: None declared

Ethical approval: The study was approved by the Institutional Ethics Committee

\section{REFERENCES}

1. Sheuly B, Ferdousi I, Akter JA. Feto-maternal outcome in cesarean section compared to vaginal Delivery in Eclamptic Patients in a tertiary Level Hospital. Journal of Enam Medical College. 2013;3(2):77-83.

2. Lelia D. Pre-eclampsia and the hypertensive disorders of pregnancy. British Medical Bulletin. 2003;67:161-76.

3. Edgar NM, Albert K, Richard R, Beatrice IH, Anthony MN. Maternal and Perinatal Ouotcome among Eclamptic Patients Admitted to Bugando Medical Centre, Mwanza, Tanzania. African Journal of Reproductive Health. 2012;16(1):35.

4. Prabhakar G, Shinde MA, Jadhav CA. Clinical study of eclampsia patients at DR. V M. Government Medical College Solapur, India. IOSR Journal of Dental and Medical Sciences. 2014;13(7):10-6.
5. Labib G, Baha S. Maternal Mortality from Preeclampsia/Eclampsia. Semin Perinatol. 2012;36:56-9.

6. Kuljit K, Shrivastav RD, Rahatgaonkar V, Bhosale UT. Study of Fetal and Maternal Outcome in Eclampsia. International Journal of Recent Trends in Science and Technology. 2014:11(1):42-4.

7. Malay S, Sanjay B, Sajal MK, Das S, Dibyendu R, Jaydeb M. Maternal Mortality associated with eclampsia in an Indian medical college: a four year retrospective study. Journal of Medicine and Medical Sciences. 2013;4(10):394-8.

8. Sandip L, Chandra MS, Ranjan PS. Early Decision of Caesarean section in Eclampsia to Improve Maternal and Perinatal Outcome. Indian Journal of Medical Research and Pharmaceutical Sciences. 2014;1(7).

9. Ali MA, Babitha MC, Lokeshchandra HC, Kavya SD, Maheen Z, Madhuri RS. A Study of changing trends of maternal mortality at the tertiary care centre, MMC \& RI Mysore, India. Int J Reprod Contracept Obstet Gynecol. 2015;4(1):239-42.

10. Muhammad J, Abbasi M.A, Zaman H. Outcome of eclampsia in patients admitted to ICU at a tertiary care teaching hospital. Khyber Med Univ J. 2013;5(4):203-6.

11. Sunita $T H$, Rathnamala DM. Eclampsia in a Teaching Hospital: Incidence, Clinical profile and response to Magnesium Sulphate by Zuspan's regimen. IOSR Journal of Dental and medical Sciences. 2013;4(2):01-5.

12. Rao PVR, Anuradha C. Eclampsia and Perinatal Outcome: A Retrospective study in a tertiary centre. $\mathrm{J}$ of Evolution of Med and Dent Sci. 2015;4(28):4755-61.

13. Rajasri YG, Jaju PB, Vanishree M. Eclampsia and Perinatal Outcome: A Retrospective Study in a Teaching Hospital. Journal of Clinical and Diagnostic Research. 2011;5(5):1056-9.

Cite this article as: Singh A, Shrivastava C. Changing trends in eclampsia and increasing cesarean delivery - an interesting retrospective study from a tertiary care hospital of Raipur, Chhattisgarh, India. Int J Reprod Contracept Obstet Gynecol 2016;5:1031-5. 